\title{
Nám í skóla og á vinnustað̌: Viðhorf og reynsla sveina, kennara og meistara af tvískiptu kerfi löggiltra iőngreina
}

Markmið rannsóknarinnar var ađ skođa hvernig nám í tvískiptu kerfi löggiltra iđngreina fer fram á Íslandi, nánar tiltekið hvort samfella sé í skipulagi námsins og samhengi milli námsins í skóla og á vinnustað. Tekin voru viđtöl við sveina, kennara og meistara (átta í hverjum hóp) í fjórum iđngreinum. Niðurstöđur benda til pess að tvískipta kerfið sé að miklu leyti rekið eins og tvö samhliða námskerfi og ekki sé nægilega hugað að pví að námið myndi samfellda heild. Samskipti eru óformleg og ábyrgð á samræmingu virđist hvergi vera skilgreind. Einnig sýndu niðurstöđur að styrkleikar námsins í skólanum eru veikleikar námsins á vinnustað og öfugt, og pví getur verið erfitt að tryggja gæði námsins í heild. Tvískipta kerfið í löggiltum iðngreinum ætti að geta bođið upp á góða heildstæða pjálfun en víða parf að lagfæra fyrirkomulag til að tryggja gæđi og samfellu náms.

Rannsóknarverkefnið var styrkt af Mennta- og menningarmálaráđuneytinu í gegnum verkefnið Nám er vinnandi vegur og af Rannsóknarsjóđi Háskóla Íslands.

Efnisorđ: starfsmenntun, löggiltar iđngreinar, framhaldsskólar, vinnustađanám, vinnustađapjálfun, tvískipt kerfi starfsmenntunar

\section{INNGANGUR}

Starfsmenntun á framhaldsskólastigi á Íslandi er ađ mestu leyti skipulögð samkvæmt tvískiptu kerfi og fer námið pá annars vegar fram innan skóla og hins vegar á starfsvettvangi. Nám í skóla og á vinnustað bætir hvort annađ upp međ ólíkum námstækifærum, lærdómi og reynslu nemenda á hvorum vettvangi fyrir sig (sjá t.d. Aarkrog, 2005; Billett, 2009; Eraut, 2004; Fuller og Unwin, 2004b; Griffiths og Guile, 2003; Schaap, Baartman og de Bruijn, 2012), en árangur byggist að miklu leyti á pví hvernig gengur ađ tryggja samhengi í náminu í skólanum og á vinnustađnum (Billett, 2014; Mulder, Messmann og König, 2015; Schaap o.fl., 2012; Sloane, 2014; Tynjälä, 2008). Markmið rannsóknarinnar er skođa hvernig samspili náms í skóla og á vinnustað er háttað og hvort námið í heild myndar samfellu og samhengi. Í peim tilgangi verður skipulag námsins skođađ, hvernig tengsl á 
milli skóla og vinnustaðar birtast og hver markmið og áskoranir námsins á hvorum stað eru. Mikilvægt er að öđlast skilning á pví hvernig nám til starfsmenntunar fer fram og hvernig best er að byggja pað upp ef ætlunin er að efla starfsmenntun. Síđastliðinn áratug hafa bæði atvinnulífið og stjórnvöld á Íslandi sett fram markmið um að auka ađsókn að starfsmenntun á Íslandi, draga úr brotthvarfi og auka skilvirkni starfsmenntakerfisins (sjá t.d. Elsu Eiríksdóttur, 2012; Forsætisráđuneytið, 2012; Mennta- og menningarmálaráđuneytið, 2009, 2014; Stýrihóp 20/20 sóknaráætlunar, 2010), en lítið hefur pokast (Ríkisendurskoðun, 2017). Til að hægt sé að vinna heildstætt að pessum markmiðum verður að skođa vandlega pað námsumhverfi sem nemendum er bođið upp á og hvernig hægt er að koma til móts við parfir peirra og væntingar. pess vegna parf að skođa samspil náms í skóla og á vinnustað í tvískiptu kerfi starfsmenntunar.

\section{BAKGRUNNUR}

Starfsmenntun (e. vocational education and training; VET) er almennt skilgreind sem menntun og pjálfun sem miðar að pví veita fólki pá pekkingu og leikni sem parf fyrir tilteknar starfsgreinar eđa atvinnulífið almennt (Cedefop, 2011). Víđast hvar í Evrópu er starfsmenntun útfærð í svokölluđu tvískiptu kerfi starfsmenntunar (einnig kallað víxlnám; e. dual system of vocational education), en pað pýđir að hluti námsins fer fram í skóla en hluti á starfsvettvangi greinarinnar (Cedefop, 2015). Nám á starfsvettvangi er ýmist kallað vinnustaðanám eða starfspjálfun á vinnustað (e. on-the-job training, workbased learning, work-based training) og er pá oft átt við ólíka hluti eftir faggreinum og löndum. Í sumum tilvikum er átt við launađan námssamning við atvinnurekanda, en í öđrum ólaunað tímabil á starfsvettvangi sem skipulagt er af skóla (Cedefop, 2011; Naidu, 2013). Hér verđur notađ orđið vinnustađanám og er pá átt við nám sem fer fram á vinnustað og er hluti af formlegu námi (tiltekinni námsbraut) par sem gerđur er samningur við fyrirtæki eđa stofnun um að veita nemanda tilskilda pjálfun (Cedefop, 2011; OECD, 2013; Mennta- og menningamálaráđuneytið, 2014; Naidu, 2013; Reglugerđ um vinnustađanám og starfspjálfun á vinnustađ nr. 840/2011). Pessi skilgreining rímar við skilgreiningu á samningsbundnu námi (e. apprenticeship) og er pá átt viđ skipulagt nám í tvískiptu kerfi par sem nemandi er samningsbundinn atvinnurekanda (Cedefop, 2011, 2015).

Á Íslandi fer starfsmenntun ađallega fram á framhaldsskólastigi og eru um 80 starfsnámsbrautir á framhaldsskólastigi hérlendis (OECD, 2013). Hér miðast umfjöllunin við nám í löggiltum iđngreinum til sveinsprófs, en samkvæmt reglugerđ um löggiltar iđngreinar (nr. 940/1999) er 51 löggilt iđngrein á Íslandi. Nám í löggiltum iđngreinum á framhaldsskólastigi á Íslandi er skipulagt samkvæmt tvískiptu kerfi starfsmenntunar. Tilhögun pess er pó ólík eftir greinum, bæði međ tilliti til lengdar og hvenær vinnustađanámið fer fram á námsferlinum (Elsa Eiríksdóttir, í prentun). Á Íslandi hefur starfsmenntun almennt verið lítið rannsökuð og engar rannsóknir hafa verið gerđar á pví hvernig nám í löggiltum ¡đngreinum fer fram hér og hvernig samspili náms í skóla og á vinnustađ er háttađ í raun. 


\section{Mikilvægi vinnustaðanáms}

Almennt virđist vera samkomulag um mikilvægi vinnustađanáms í starfsmenntun milli peirra sem rannsaka og fjalla um starfsmenntun og stjórnvalda (Billett, 2009; Forsætisráđuneytið, 2012; INAP Commission 'Architecture Apprenticeship', 2013; Jón Torfi Jónasson, 1998; Mennta- og menningarmálaráđuneytið, 2014; Nielsen og Kvale, 2006; OECD, 2009; Schaap o.fl., 2012; Tynjälä, 2008). Enda er vinnustađanám skilgreint sem páttur í starfsmenntun í flestum Evrópulöndum (Cedefop, 2015). Meðal rökstuđnings fyrir mikilvægi pess er: (1) Ađ vinnustađanám býður upp á öflugt námsumhverfi par sem pjálfun fæst í starfinu sjálfu og leiđir pannig til dýpri skilnings nemenda og aukinnar starfshæfni peirra. (2) Að með náminu má auka nýliđun í störfum pví pannig geta nemar og vinnuveitendur kynnst og pá opnast atvinnumöguleikar fyrir ungt fólk að skóla loknum. (3) Vinna nema getur verið mikilvæg fyrir atvinnurekendur og pví lengra sem peir eru komnir í pjálfun sinni, peim mun mikilvægara verður vinnuframlag peirra. pað getur vegið аð nokkru upp á móti kostnađi við pjálfunina. petta fer pó eftir pví hvernig pjálfun nema er skipulögð og hvort peir fást við verkefni sem auka framleiðni. (4) Vinnustađanám tryggir að í verknámi fáist næg pjálfun á starfsvettvangi. pađ er, að nemar öđlist pá færni og kunnáttu sem parf til að starfa við greinina og vinnuveitendur fái pjálfađ starfsfólk á peim sviðum par sem pess er pörf.

Pó að almennt samkomulag ríki um kosti tvískipts starfsmenntakerfis og mikilvægi vinnustađanáms er ekki sjálfgefið ađ nám eigi sér stað með pví að nemendur séu sendir á vinnustađ. Skiptar skođanir eru á pví hvernig skipulagi námsins er best háttað og sérstaklega hvernig hægt sé að tryggja gæđi starfsmenntunar og að nemar fái pá pjálfun sem ætlast er til (sjá t.d. Billett, 2009; Eraut, 2004; Tynjälä, 2008). Par sem rannsóknir á vinnustađanámi á Íslandi eru af skornum skammti er ekki hægt að fullyrđa að pessi gagnrýni eigi við rök að styđjast hér, en rannsóknir hafa sýnt að petta geti verið vandamál í vinnustađanámi (Billett, 2009; Brooker og Butler, 1997; Cornford og Gunn, 1998; Fuller og Unwin, 2004a). Petta er mikilvægt pví ein af forsendunum fyrir gæđum náms á vinnustað er skuldbinding nemenda við fagið og vinnustaðinn sem skapast með viðurkenningu á pátttöku peirra og vinnuframlagi (Eraut, 2004).

\section{Nám í skóla og á vinnustað: Samspil og einkenni}

Rannsóknir sýna ađ árangur af tvískiptu kerfi starfsmenntunar byggist á skilvirku samspili náms í skóla og á vinnustað (Billett, 2014; Mulder o.fl., 2015; Schaap o.fl., 2012; Sloane, 2014; Tynjälä, 2008). Tvískipt kerfi gerir kröfur um góđa samhæfingu pessara ólíku námsstaða en rannsóknir hafa gefið til kynna að nemendur eigi oft erfitt með að tengja pað sem er lært í skóla við pað sem lærist á vinnustað og öfugt. Yfirfærsla, sem felst í pví að geta beitt og aðlagað pekkingu og leikni að nýjum ađstæðum, virđist vera vandamál (Billett, 2013; Guile og Young, 2003; Wahlgren, 2009). Rök hafa verið færð fyrir pví að erfiðleikar í yfirfærslu stafi af ólíkum og oft ósamkvæmum áherslum skóla og vinnustađar. í skóla er áherslan pannig á námsferlið og ađ nemandinn öđlist almenna fagtengda pekkingu og leikni en á vinnustað aftur á móti fyrst og fremst á útkomu vinnuferlisins, sértæka pekkingu og leikni, og framleiđni (Billett, 2009; Lindberg, 2003; Schaap o.fl., 2012; Tynjälä, 2008). Að sama skapi er pekkingaröflun og námsferli nemenda ólíkt í skólum og 
vinnustaðanámi. Pað virđist henta betur að kenna fræđilegan kenningagrunn í skóla, en vinnustaðanám gefur nemandanum tækifæri til að tengja fræđilega pekkingu við reynslu og hagnýtingu. Aftur á móti getur verið erfitt að fá yfirsýn og skilning á fræđilegu samhengi á vinnustađ, par sem framsetning pekkingar er par oft tilviljunarkennd og áherslan aðallega á útkomu og skilvirkni (Nielsen og Kvale, 2006; Schaap o.fl., 2012; Wahlgren, 2009). Vinnustaðurinn býður upp á pátttöku í ađ leysa verkefni við raunverulegar aðstæður, sem erfitt getur reynst ađ skapa í skóla, og pátttaka í vinnu á starfsvettvangi er mikilvæg til að skapa faglega sjálfsmynd nemenda (Schaap o.fl., 2012). Í skólum er ađaláherslan á námsferli nema, að ígrunda ađferđir og nálgun að verkefnum, öđlast fræđilega kunnáttu og almenna færni. Pannig eru verkefni par byggð upp í kennslufræðilegum tilgangi en á vinnustađnum virđist sem frumkvæði nemenda og kjarkur til að spyrja og leita uppi námstækifæri skipti sköpum um pađ hvort nám eigi sér stað pví að áherslan par er á vinnuna, tiltekna færni, framleiðni, pjónustu við viðskiptavini, árangur lausnaraðferđa og afköst (Eraut, 2004; Schaap o.fl., 2012; Tynjälä, 2008).

pannig virđast ákveđnir pættir lærast betur í skóla (t.d. kenningar, fræđileg umgjörð og almenn grundvallarfærni) en ađrir lærast betur við vinnu (t.d. samskipti við viðskiptavini, hvernig á að vinna undir álagi og pjálfun samhengisbundinnar færni). Einnig virđist afrakstur námsins vera ólíkur, par sem nemendur í vinnustađanámi sýna gjarnan góđa færni í ađ leysa verkefni í faginu en geta illa útskýrt hvað peir eru að gera og af hverju, en nemar í skóla eiga auðvelt með útskýringar en hafa ekki sömu getu til að leysa verkefni í faginu (Lindberg, 2003; Schaap o.fl., 2012). Pessi áherslumunur í skóla og á vinnustađ leiđir pannig af sér ólíka pekkingu, leikni og viðhorf.

pví er mikilvægt að nýta styrkleika hvors námsumhverfis fyrir sig og ađstođa nemendur við að tengja parna á milli og yfirfæra pekkingu og leikni á árangursríkan hátt. Rannsóknir sýna að samhæfing er lykilatriði í pessu samhengi, en pað pýđir að samræma verđur nám í skóla og á vinnustað svo pað styðji hvort annað. Samræming af pessum toga krefst pess að kennarar viti hvað fram fer á vinnustađnum og meistarar séu upplýstir um pað sem á sér stað í skólanum (Mulder o.fl., 2015; Sloane, 2014; Tynjälä, 2008).

Gerður hefur verið greinarmunur á pví sem kallað er hefðbundið líkan (e. traditional model) og öđrum líkönum sem setja samhæfingu á reynslu og námi á vinnustað og í skóla í forgrunn (Guile og Griffiths, 2001; Tynjälä, 2008). Hefðbundið líkan gerir ráđ fyrir að pað dugi að senda nemendur á vinnustað og nám gerist sjálfkrafa með vinnunni. Nemendur sjá sjálfir um að laga sig að kröfum vinnustađarins og ekki er talin sérstök pörf á leiðbeiningum umfram almenna verkstjórn yfirmanna. Hefðbundinni nálgun hefur verið stillt upp sem andstæðu við ýmsa aðra nálgun sem byggist á tilteknum kennslufræðilegum áherslum eđa kenningum. Einn stærsti munurinn er sá að í hefðbundna líkaninu er ekki gert ráđ fyrir samhæfingu og samskiptum á milli skóla og vinnustađar en pađ er lykilatriði í öđrum líkönum. Pví hafa fræðimenn sem fjalla um kennslufræði starfsmenntunar lagt áherslu á ađ nám í tvískiptu kerfi purfi ađ mynda heildstætt ferli (Billett, 2009; Guile og Griffiths, 2001; Mulder o.fl., 2015; Schaap o.fl. 2012; Sloane, 2014; Tynjälä, 2008). paঠ krefst meðal annars samfelldra og stöđugra samskipta milli kennara og peirra sem hafa tilsjón međ námi á vinnustađ. 


\section{Nám í tvískiptu kerfi löggiltra iőngreina á Íslandi}

Rannsóknir sýna að tvískipt kerfi starfsmenntunar hefur mikilvæga kosti, en einnig að árangur pess byggist á góđu samspili náms í skóla og á vinnustađ. Markmið rannsóknarinnar sem hér er fjallađ um var ađ skođa reynslu sveina, kennara og meistara af pví hvernig nám í tvískiptu kerfi löggiltra iđngreina fer fram á Íslandi i fjórum iđngreinum međ ólíka útfærslu á samspili náms í skóla og á vinnustađ. Rannsóknarspurningin er pví: Er tvískipt nám í löggiltum iðngreinum skipulagt pannig að pađ myndi samfellu og samhengi? Fengist er við spurninguna í premur liðum: (1) Hvernig er námið skipulagt með tilliti til sampils náms í skóla og á vinnustađ? Skipulag námsins vísar hér til uppbyggingar pess og peirra pátta sem hafa áhrif á pađ og stýra pví. (2) Hvernig er tengslum á milli pessara ólíku hluta námsins háttađ? Með tengslum er átt við sambandið á milli skóla og vinnustađar og samskipti og samstarf kennara og meistara. (3) Hver eru markmið og áskoranir náms í skóla annars vegar og á vinnustað hins vegar? Markmið snúast pví um reynslu nemenda af nálgun námsstađanna, og síđan hvađa kennslu og pjálfun nemendur eiga kost á og í hverju áskoranir liggja par.

\section{AĐFERE}

Rannsóknin er viđtalsrannsókn par sem hálfopinn viđtalsrammi (sjá t.d. Bryman, 2012; Flick, 2014; Kvale, 1996) var notađur til ađ draga fram ólík viðhorf til náms og kennslu í tvískiptu kerfi löggiltra iđngreina á Íslandi. Tekin voru viđtöl viđ prjá hópa viđmælenda í fjórum ólíkum löggiltum iđngreinum: nýlega brautskráđa sveina í iđngrein, meistara sem hafa nýlega haft tilsjón með nema á vinnustað og kennara sem kenna iðngrein í framhaldsskóla.

\section{Val á löggiltum iőngreinum}

Valdar voru fjórar löggiltar iđngreinar sem fulltrúar fyrir tiltekna tilhögun á samtvinnun náms í skóla og á vinnustað og lengd vinnustađanáms. Námskrár 34 löggiltra iđngreina ${ }^{1}$ voru skođađar og pær flokkađar eftir pví sem fram kom í námskrám um lengd vinnustađanámsins, hvar námið ætti að hefjast og einnig hvar bví ætti að ljúka (Elsa Eiríksdóttir, í prentun). Lengd vinnustađanáms var greind í prjá flokka: stutt (24-48 vikur, fimmtán iðngreinar), međallangt (60-80 vikur, tíu iđngreinar) og langt (96-126 vikur, níu iðngreinar). Skilyrđi um upphaf og lok náms féllu í fjóra flokka: 1) upphaf í skóla og lok náms í skóla (átta iđngreinar), 2) upphaf í skóla og lok náms á vinnustađ (tólf iđngreinar), 3) upphaf í skóla og lok náms annađhvort í skóla eđa á vinnustađ (sjö iđngreinar), 4) upphaf frjálst (skóli eđa vinnustađur) en lok náms í skóla (fjórar iđngreinar). Iđngreinarnar fjórar voru valdar úr hverjum flokki tilhögunar og lengdar vinnustađanáms. Pannig var reynt að tryggja að fram kæmu sjónarmið úr iđngreinum með ólíka tilhögun tvískipta kerfisins. Að auki var reynt að líta til kynjahlutfalls. Árið 2014 voru meira en 70\% nemenda annaðhvort karlar eđa konur í 27 af 31 iđngrein sem upplýsingar voru til um (Hagstofa Íslands, 2017). par af voru 20 iðngreinar par sem hlutfall annaðhvort karla eđa kvenna var 90-100\%. Kynjahlutfall nemenda í iðngreinum er pví mjög skekkt. En einnig eru karlagreinarnar 
fleiri; af pessum 27 löggiltu iðngreinum sem höfðu meira en 70\% nemenda af öðru kyninu var 21 grein par sem hallađi á konur en ađeins sex greinar par sem hallađi á karla. pví voru valdar tvær karlagreinar, ein kvennagrein og ein iðngrein par sem hlutfallið var nokkuð jafnt.

Ekki verður tilgreint um hvaða iðngreinar ræðir til að halda trúnaði við viðmælendur eftir fremsta megni. Iðngreinar eru flestar fámennar og sumar eru aðeins kenndar á örfáum stöđum. Pví gæti verið auðvelt að komast að pví við hvern er rætt ef gefnar væru upplýsingar um greinarnar.

\section{Pátttakendur}

Alls voru 24 pátttakendur fengnir í viðtal, sex úr hverri af iðngreinunum fjórum. Pátttakendurnir skiptust jafnt í prjá hópa: (1) sveinar sem höfđu lokið sveinsprófi í iđngreininni á síđastliđnum tveimur árum ( $n=8$, á aldrinum 21-46 ára, prjár konur og fimm karlar), (2) átta meistarar sem höfđu haft tilsjón međ nema í vinnustađanámi á síđastliđnum tveimur árum ( $n=8$, á aldrinum 35-70 ára, prjár konur og fimm karlar) og (3) átta kennarar sem kenna iđngreinina í framhaldsskóla ( $n=8$, á aldrinum 35-65 ára, fjórar konur og fjórir karlar). Sex af 24 pátttakendum bjuggu og störfuđu utan höfuðborgarsvæđisins. Pátttakendur voru valdir af handahófi úr pýđi hvers hóps í hverri iđngrein og er pví um lagskipt tilviljunarúrtak að ræða (e. stratified random sampling) (Bryman, 2012).

Upplýsingar um pýđi kennara voru fengnar af heimasíđum framhaldsskóla og höfundur valdi handahófskennt úr pýđi hverrar iđngreinar. Upplýsingar um nýlega brautskráđa sveina og meistara sem höfðu haft tilsjón međ vinnustađanámi nema nýlega voru fengnar í samstarfi við fræðslusetrið Iðuna og sá starfsmaður Iðunnar með aðgang að gagnabanka setursins um að velja handahófskennt úr býđi. Haft var samband við alla sem lentu í úrtaki og beđið um viðtal. Ef viðkomandi neitađi (alls sjö) eđa ekki náđist í hann eđa hana með neinum ráđum (alls sex) var annar einstaklingur valinn af handahófi í stađinn par til fengust átta viðmælendur í hvern hóp. Petta gerđi pað að verkum að erfitt reyndist að halda jafnvægi í kynjahlutfalli viðmælenda og á endanum hallađi á konur í premur af fjórum iðngreinum.

Haft var samband við mögulega pátttakendur í tölvupósti fyrst en síđan síma ef ekkert svar barst við tölvupósti. Ef pátttaka var sampykkt mæltu rannsakandi og viðmælandi sér mót.

\section{Viðtölin}

Viđtölin voru tekin á tímabilinu október 2014 til apríl 2015 og fóru í flestum tilfellum fram á vinnustöđum viðmælenda. Lengd peirra var á bilinu 30 til 75 mínútur. Viðtölin voru hljóđrituð með sampykki pátttakenda og afrituð til úrvinnslu. Höfundur tók tíu viðtöl en meistaranemi og doktorsnemi tengdir rannsókninni tóku sjö hvor.

Viðtalsrammi var notađur og aðlagađur fyrir hvern hóp. Pannig fengu sveinar, kennarar og meistarar sambærilegar spurningar en spurt var um samspil bóklegra og verklegra pátta iđngreinarinnar í skóla, samspil náms í skóla og á vinnustađ, ferilbók, sveinspróf og grundvallarfærni í faginu. Viđtalsramminn var rýndur og prófađur á tveimur einstaklingum með menntun í iðngrein áđur en viðtölin voru tekin. Í pessu ferli var orđalag ađlagað 
og röðun spurninga ákveđin endanlega. Eftir að fyrstu viðtölin voru tekin hittust höfundur og doktors- og meistaranemar sem tóku viðtölin og ræddu orđalag, mögulegan misskilning og nálgun. Pannig var reynt ađ auka réttmæti gagnasöfnunarinnar.

\section{Greining gagna}

Viđtalsramminn stýrđi efni umræđnanna og í úrvinnslu voru settar fram grundvallarspurningar sem sneru ađ samspili náms í skóla og á vinnustađ í samræmi viđ rannsóknarspurningarnar. Spurningarnar fjölluđu m.a. um pađ hvernig nemendur höguđu námi sínu í heild, hvað peir gerđu í skólanum, hvað peir gerđu í vinnustađanáminu og um upplýsingaflæđi á milli skóla og vinnustađa. Að auki voru viðtölin pemagreind við úrvinnslu (Braun og Clarke, 2006) og pemun flokkuð undir efnisflokkana prjá. Umfjöllun um niðurstöður er pví bundin rannsóknarspurningum og áherslum í viđtalsramma en einnig pemum sem komu upp við greiningu gagnanna eftir á.

\section{Siðferðilegir pættir}

Í upphafi hvers viðtals fór rannsakandi yfir tilgang rannsóknarinnar, hvernig trúnađur við viðmælendur yrði tryggður og hvernig farið yrđi með gögnin. Viðmælandi var pví næst beđinn að lesa og skrifa undir upplýst sampykki um pátttöku par sem gerđ var grein fyrir tilgangi rannsóknarinnar, rétti pátttakenda og hvernig trúnađur við pá yrđi tryggđur (Flick, 2014; Kvale, 1996). Rannsóknin var tilkynnt til Persónuverndar.

Par sem trúnađi hefur verið heitið við viðmælendur verður ekki gerð grein fyrir pví um hvaða iðngreinar ræđir, hvaða skóla eđa vinnustađi. Einnig er leitast við að gefa eins litlar upplýsingar og hægt er um viðmælendur, t.d. er ekki gerð grein fyrir starfsreynslu, útskriftarári eđa aldri einstakra viðmælenda. Viðmælendum hefur verið gefið dulnefni í umfjöllun um niđurstöđur (sjá töflu).

Tafla. Dulnefni viðmælenda eftir hópum

\begin{tabular}{ccc} 
Sveinar & Kennarar & Meistarar \\
\hline Hafpór & Andrea & Berglind \\
Hannes & Ásta & Einar \\
Karen & Gylfi & Elín \\
Lára & Konráð & Rósa \\
Markús & Lína & Rúnar \\
Sonja & Loftur & Tómas \\
Viktor & Reynir & Viðar \\
Pór & Tinna & Vignir \\
\hline
\end{tabular}




\section{NIĐURSTÖĐUR}

Í umfjöllun um niðurstöđur verđur sjónum beint að peim páttum sem virđast vera sameiginlegir greinunum fjórum og pannig óháđir tiltekinni tilhögun tvískipta kerfisins. Rannsóknarspurningin var: Er tvískipt nám í löggiltum iðngreinum skipulagt pannig að pað myndi samfellu og samhengi? Umfjöllun um niðurstöður er skipt í eftirfarandi kafla eftir premur liðum rannsóknarspurningarinnar: (1) Skipulag náms í tvískiptu kerfi með tilliti til sampils náms í skóla og á vinnustađ, (2) tengsl á milli náms í skóla og á vinnustað og (3) markmið og áskoranir náms í skóla og á vinnustað.

\section{Skipulag náms í tvískiptu kerfi}

Í umræðu um skipulag námsins í heild voru peir „flöskuhálsar“ sem myndast í kerfinu pegar ekki eru nægilega mörg samnings- eđa skólapláss fyrir nemendur áberandi pema í máli viđmælenda. Flöskuhálsar í kerfinu voru sveinunum mikið áhyggjuefni og hjá peim snerist umræðan um skipulag námsins fyrst og fremst um erfiðleika við að komast að í skóla eđa vinnustađanámi. Í tveimur af peim fjórum iđngreinum sem valdar voru virtist vera erfitt að fá vinnustađanámssamning. Markús, sveinn, sagđi: „Ég held að ég hafi haft samband við [öll fyrirtæki] sem ég fann." Sonja, annar sveinn, sagđist vera heppin ađ hafa komist í vinnustađanám: „Ég tel mig vera heppna að hafa náð starfssamningi, miđað við að við vorum 24 og vorum fjögur sem náđum samningi.“ Karen lýsti svipuđu ástandi: „Pannig að pú sérð pað að við byrjuđum tólf í mínum bekk, prjú sem kláruðum, og ég veit að einn nemandi úr mínum bekk er kominn á samning núna, ég útskrifađist 2013 [ári áđur en viðtalið er tekið]!“ í öđrum greinum lýstu viðmælendur erfiðleikum við að geta klárað pađ sem til væri ætlast í skólanum. Petta gat gerst ef mikil ađsókn var að skólanum, sem pá gat ekki tekið við öllum vegna ađstöđuleysis, eins og til dæmis einn meistarinn, Vignir, lýsti: „,pað er bara orđin núna svo mikil ađsókn að ég er að heyra hjá nemendum að pau hafa ekki komist inn í skólann." Einnig gat pađ verið vandamál ef ekki náđust nógu margir nemendur til að áfangi yrđi kenndur. Til dæmis purfti Karen ađ bíđa í rúmt ár eftir ađ halda áfram í skólanum par sem ekki voru nógu margir nemendur til ađ peir áfangar sem hún purfti að taka væru kenndir.

Pessar niðurstöđur sýna að flöskuháls getur myndast hvort sem er í skólahlutanum eđa vinnustaðanámshlutanum, en í báđum tilvikum getur pað leitt til tafa á námslokum, eđa brotthvarfs í versta falli, eins og til dæmis meistarinn Berglind lýsti: „Рað auðvitað hefur alltaf verið [brottfall úr stéttinni], en er extra mikið núna af pví að bað er svo erfitt að komast á samning.“ Reynir, einn kennarinn, sagđi „Ég pekki dæmi, fleiri en eitt og fleiri en tvö, að nemendur komist ekki að hjá meistara og par af leiđandi geta peir ekki tekið sveinspróf, eru bara fastir í kerfinu ... frá sjónarhóli nemendanna skítastađa í rauninni.“ Afleiđingin er sú ađ bođið er upp á nám án pess ađ hægt sé að tryggja námslok. Viđmælendur voru meðvitađir um petta vandamál. Eins og Ásta, einn kennarinn, spurđi: „Til hvers að vera að bjóđa upp á nám sem ekki er hægt að klára?“"

Annað pemað sem viðmælendum var tíđrætt um sneri að pví hvernig náminu sem heild er stýrt og pað skipulagt. Samkvæmt viðmælendum er pað á ábyrgð nemenda að útvega sér samning á vinnustađ og einnig að skipuleggja samtvinnun námsins í skólanum 
og á vinnustaðnum. pað virtist vera ólíkt eftir ¡đngreinum hversu fastákveðið skipulag pessarar samtvinnunar var. Í einni grein lýstu allir viðmælendur sömu tilhögun á samtvinnun námshlutanna, en í hinum premur lýstu peir uppbyggingu námsins í sinni grein oft á mjög ólíkan hátt. Í sumum tilvikum virtist pað vera einstaklingsbundið en í öđrum háđ tiltekinni skólastofnun. Til dæmis lýsti Loftur, einn kennarinn, pví hvernig nemendur ljúka alltaf skólanum fyrst og síđan vinnustađanáminu, en Reynir, annar kennari í sama fagi en við annan skóla, sagđi nemendur yfirleitt ljúka vinnustađanáminu fyrst en koma svo aftur í skólann fyrir sveinsprófið. pađ virđist pví sem ólíkar venjur hafi skapast í pessum tveimur skólum hvað uppbyggingu námsins varđar.

í flestum tilvikum virtust viðmælendur vera sáttir við petta fyrirkomulag og pađ sýnir vissan sveigjanleika í kerfinu sem gæti hentað mörgum. Eins og Ásta lýsir: „Námsskipulag er samkomulag á milli nemenda og meistara pegar pau eru komin á samning og pađ er hægt að skipuleggja bađ nokkurn veginn eins og hentar peim báđum hverju sinni.“ I ́ framhaldi lýsir hún pví hvernig vinnustađanámiđ getur bæđi dreifst á sumar- og jólafrí, hvernig sumir vinna međ skóla en ađrir taka sér hlé frá skólanum.

pó virtist pessi sveigjanleiki í sumum tilvikum gera námið í heild ruglingslegra, eins og Pór lýsir:

Pað voru alltaf einhver svona símtöl fram og til baka og stundum svona, pú ferð í pessa röđ, svo beið maður í einhverri röð og pá er bent á einhverja aðra röð. pannig að, já, mér fannst ekki alveg nógu skýr skilabođin ... Ég man bara að petta var rosalega mikið vesen. petta einhvern veginn skýrđist ekki.

Svar Pórs er áhugavert fyrir pær sakir að parna lýsir hann pví hvernig hann fékk ekki skýr svör um pað hvernig hann ætti að haga námi sínu. Petta gefur til kynna að fórnarkostnađur sveigjanleikans geti verið takmörkuð sýn yfir námið í heild og ekki sé nægilegt utanumhald pegar á reynir.

Viđmælendur voru spurđir hver ætti að bera ábyrgð á náminu í heild og yfirleitt sögđu peir ađ nemandinn ætti fyrst og fremst ađ bera ábyrgð á eigin námi, en pegar rætt var um yfirsýn yfir skipulag námsins og námsferil nemandans töldu flestir viðmælendur að skólarnir ættu að bera ábyrgð á náminu í heild. Undantekning var á pessu í greininni par sem vinnustađanámið var lengst. par voru viðmælendur sammála um að meistarar ættu að bera ábyrgð á námsferli nemandans, eins og Konráđ, kennari, sagđi: „við erum með meistarakerfi og pá purfum við ađ smíđa petta pannig að meistarinn beri ábyrgđina.“ Skođanir á pví hvar ábyrgđin skuli liggja virđast pví ađ einhverju marki háđar pví hvar stærsti hluti námsins fer fram.

Niðurstöđur benda til pess að í skipulagi námsins sé ekki gert ráđ fyrir tengslum skóla og vinnustađar og að nám í skóla og á vinnustað sé í raun ađskilið frekar en heildstætt. Svo virđist sem hvorki kennarar né meistarar beri skilgreinda ábyrgð á heildarnámsferli nemandans. Pađ er í höndum nemandans ađ finna sér pláss í vinnustađanámi og pađ bitnar einnig á nemandanum ef illa gengur ađ komast á samning hjá vinnuveitanda eđa ljúka skólanum. 


\section{Tengsl á milli náms í skóla og á vinnustaơ}

í viðtölunum kom skýrt fram að tengsl iđngreinakennara í framhaldsskólum og iđnmeistara sem sjá um vinnustaðanám nemenda voru fyrst og fremst óformleg og byggðá persónulegum kynnum. Samskipti milli peirra um stöðu og framgang nema virtust ekki vera formlegur hluti af peim skyldum sem peir taka sér á hendur við kennslu nema. Til dæmis sagði Andrea, kennari:

Eins og petta er núna pá er petta [hik], kannski aukavinna á kennara sem er svo ekkert, kemur hvergi fram. Skilurđu. petta er bara týpískt, petta er í rauninni bara good-will frá starfsfólki, hvað pað leggur mikið extra á sig.

Peir kennarar sem sögðust vera í samskiptum við meistara eða forsvarsmenn fyrirtækja töluðu pannig um pað sem aukalega vinnu af pví að peim fyndist pað sjálfum mikilvægt, ekki af pví að til pess væri ætlast af peim.

Bæði kennarar og meistarar sögðust fá upplýsingar í gegnum persónuleg tengsl. Til dæmis sagđi Lína, einn kennarinn: „Já, ég hef yfirleitt tengingu inn á flesta stađina. En pað er bara, ég auðvitað parf ekki að gera pað, en ég hef yfirleitt fylgt nemunum." Einar, meistari, lýsti sömuleiđis góđum persónulegum tengslum við kennara og útskýrđi pað pannig að kennararnir hefðu allir unnið við fagið áður og hann hefði unnið með sumum peirra. Loftur, kennari, lýsti pví einmitt sem kosti að hafa stuttu áđur unnið við fagið pví:

... nemendur eru mikið að leita til mín um pað hvar peir eigi að sækja um, fyrirtækin leita líka mikið til mín upp á að benda á líklega nemendur. Pað er bara fínt, mađur getur pá hjálpað til ađeins ađ koma peim af stađ ... ég svona preifa á nemandanum: Á hverju hefur pú áhuga? ... og pá getur mađur bent peim á réttu ađilana. Og svona mælt međ peim pá, og pađ hefur bara gengið vel og allir sáttir.

Pađ kom einmitt víđar fram í máli bæđi kennara og meistara ađ óformlega séu kennarar oft eins konar miðlarar fyrir nemendur og meistara. Beiðni um međmæli eđa ábendingar um nemendur var oft ástæða pess að meistarar sögðust hafa haft samband við kennara. Til dæmis sagđi Rósa, meistari: „Ég hafđi samband við skólann, reyndar út af kunningsskap, og kennari aðstođađi mig við að velja nemanda sem hún hélt að mundi henta.“ Síđan bætti hún við að pað gæti verið mjög gott að fá ađstoð frá einhverjum sem pekkti bæði meistarann og nemandann. Flestir kennararnir virtust líta á petta sem sjálfsagđan hlut, en í einu tilviki nefnir kennarinn að pađ sé erfitt pegar fyrirtæki hringi og biðji um ábendingar. Sumum getur pví fundist petta setja sig í ópægilega stöđu gagnvart nemendum.

Ef samskipti kennara og meistara eru helst í gegnum persónuleg tengsl er hætt við að samskiptin verði brothætt. Pannig skapast hætta á að tengsl milli skóla og vinnustađar rofni ef tiltekinn kennari eđa meistari lætur af störfum, par sem pau virðast hvergi vera skilgreind eđa formgerđ í kerfinu. Aftur á móti lýstu allir kennarar og meistarar yfir áhuga á meiri og formlegri samskiptum á milli skólans og atvinnulífsins, eins og Elín meistari segir:

Mér finnst pau dálítið mikið halda sig út af fyrir sig parna í skólanum ... [tengslin] ættu ađ vera töluvert meiri ... Kannski bara að reyna að hittast oftar, ræða, halda kannski fundi einu sinni á ári ... getum við ekki bara haldið einn smá fund?! 
Viđmælendur lögđu áherslu á ađ betri og meiri samvinna myndi tryggja gæđi námsins í heild. Viđar, meistari, benti til dæmis á pađ hversu mikilvægt formlegt samband meistara og kennara væri svo hægt væri að vinna sameiginlega að menntun nemanna:

Ég held að pað ætti að vera formlegt samband með pað, að menn gætu skipst á ákveđnum trúnađarupplýsingum og pá er ég að tala um til pess að vinna međ nemendanum, ekki til að vinna gegn honum. Sem gæti pá auðveldað öllum ađ̛ilum að klára pađ sem til er ætlast.

Pannig kom fram í máli meistara áhugi á ađ fá upplýsingar frá skólunum um frammistöđu nemenda og hvernig náminu par væri háttađ. Eins og kemur fram í máli Berglindar:

pannig ađ ég mundi alveg vilja fá, sem kennari [úti i atvinnulífinu], upplýsingar um pađ hvernig nemandanum vegnar ... Mér finnst alveg að ég mætti hringja í kennarana. Segja, heyrđu, bíddu, hvernig gengur henni í pessu? parf ég að taka á bví af pví hún var ekki búin að læra petta nógu vel?

Einn meistari, Vignir, sagđi að pað væri ópægilegt að purfa að afla sér allra upplýsinga um nemendur sjálfur, að purfa alltaf að biđja um petta. Pað sama kom fram í máli Tómasar: „Ég parf að biđja nemendur um einkunnir, sko. Ég veit ekki hvort peir megi segja mér einkunnir eđa eitthvað svoleiđis, eđa hvernig gangi, hvernig skróp er eđa svoleiđis. pað væri fínt að vita pađ.“ Meistarar voru almennt ekki vissir um hvaða upplýsingar peir mættu eđa ættu að fá um nemendur, en Gylfi, einn kennarinn, sagđi pað skýrt: „Meistari hefur ígildi kennara ... og við höfum upplýsingaskyldu gagnvart meistara um mætingu og almennan námsferil. ... •að hefur ráđuneytið sagt, pað er úrskurđur. Svo okkur ber að upplýsa meistara, svo ađ ábyrgð meistara er mikil.“

Í pessu samhengi ræddu kennarar um pađ hversu óljóst hlutverk peirra væri međan á vinnustađanámi stæđi og vildu fá par skýrara hlutverk sem skilgreint væri sem hluti af starfi peirra. Hugsunin var sú ađ pannig væri auđveldara að tryggja gæđi námsins í heild með samstarfi og eftirliti, eins og kemur fram í máli kennarans Línu:

Ég mundi vilja ađ skólinn mundi bera ábyrgđ á nemanum og pað væri undir eftirliti okkar sem væri starfspjálfunin, skilurðu, vinnustađanámið. Já, af pví par kæmum við t.d. í veg fyrir pessa einhæfingu. Ađ neminn sé bara látinn í ađ gera allt of lítið, sko. En ef pađ er á ábyrgđ skólans, einhver gátlisti og einhver eftirfylgni, pá mundi pað auðvitað breytast.

Kennarar lýstu pannig yfir áhuga á ađ koma meira ađ námi nemenda međan peir væru í vinnustađanámi og meistarar vildu fá meiri upplýsingar um frammistöđu nemenda í skólanum. Peir virtust pó að einhverju leyti fá pessar upplýsingar frá nemendunum. Pegar kennarar voru spurđir hvort peir vissu hvað nemendur gerđu í vinnustađanáminu og meistarar spurđir hins sama um skólann kom fram að peir fengju slíkar upplýsingar frá nemendunum, til dæmis svarađi Reynir, einn kennaranna: „Já, bara bað sem peir [nemarnir] segja mér, sko. Peir koma inn aftur, sko, peir koma inn og eru hjá okkur í lokin ... pá náttúrulega heyrir mađur hvar peir hafa verið að vinna og auðvitað vilja miðla af sinni reynslu.“ Og Berglind, meistari, sagđi: „Já, ég svona nokkurn veginn veit pað, í gegnum mína nemendur, peir segja mér svona ýmislegt."

Aðspurđir sögðust margir sveinarnir ekki hafa orđið mikið varir við samskipti kennara og meistara og sögðust ekki vita hvort kennarar vissu hvað peir gerðu á vinnustaðnum eđa meistarar hvað peir gerđu í skólanum. Ađrir sögðu samskiptin takmörkuð, eins og 
kemur fram hjá Póri pegar hann var spurđur hvernig honum hefđi fundist upplýsingaflæđið á milli skóla og vinnustađar:

Ekki gott. Alls ekki. Minn meistari var rosa busy, ég held ađ flestir meistarar séu busy. Ef hún fékk póst pá kannski las hún hann eftir viku, eitthvađ svoleiðis, og kom međ svona, einhverjar grófar upplýsingar. pađ var heldur ekki að hún fengi einhvern svona upplýsingapóst.

Í enn öđrum tilvikum lýstu sveinarnir góđum samskiptum. Karen sagđi frá pví ađ hennar meistari væri gestakennari í skólanum og hún vissi til pess að kennarar og meistarar hittust á fundum. Eins sagđi Lára frá pví að augljóst hefđi verið að meistari hennar væri í sambandi við kennara í skólanum, pó hún vissi ekki nákvæmlega hvernig pví hefði verið háttađ.

Í heild má ráđa af máli viđmælenda ađ pađ sé mjög misjafnt hvort meistarar og kennarar ræđa saman um nemendur, samskipti á milli kennara og meistara eru óformleg og byggjast á persónulegum kynnum ef um pau er að ræđa. pá virđist upplýsingaflæđi gjarnan vera í gegnum nemendurna. Pó kemur fram skýr áhugi á meiri og formlegri samskiptum á milli skóla og atvinnulífs almennt og kennara og meistara sérstaklega.

\section{Markmið̋ og áskoranir náms í skóla og á vinnustað}

Í umræđu um einkenni náms í tvískipta kerfinu kom fram að viðmælendur töldu skóla og vinnustað hafa mjög ólík markmið. Greinilegt var að í sumum iđngreinum var töluverð togstreita á milli kennara og meistara um hvað ætti að kenna hvar, til dæmis hvar pjálfun grundvallarfærni í faginu ætti ađ fara fram. Sveinarnir ræddu aftur á móti frekar reynslu sína af pví hversu ólík nálgun námsstađanna gat verið. Til dæmis kom fram ađ í skólanum fengju nemendur nægan tíma til að vinna verkefnin og ígrunda pað sem peir væru að gera en á vinnustað væri áherslan á að læra að vinna undir tímapressu og pví mikilvægt að geta unnið hratt og örugglega undir álagi. Til dæmis sagđi Markús, einn sveinninn:

petta er náttúrulega alveg gjörólíkt ... pað er allt annað að vera í skóla og gera verkefni og hafa allan tíma í heimi til að gera bau. Síđan kemur pú á vinnustađinn og reynir ađ gera verkefnið eins fljótt og hægt er, svo kúnninn fái pađ sem fyrst í hendurnar, án pess að pađ bitni á gæðum í verkinu.

Einnig kom fram að í skólanum væri fyrst og fremst lögð áhersla á vandvirkni og nákvæmni - að gera hlutina á „réttan“ hátt - á međan ýmis „trikk“ og styttri leiðir að markmiðinu væru leyfđar á vinnustað. Hafpór, einn sveinninn, lýsir pessu svona:

pað er rosa áhersla lögð á petta í skólanum [að allt verði fallegt og flott], svo var bara hlegið að manni pegar mađur kom í vinnuna og ætlađi að vera vođa flottur. Pað eru ekki góð vinnubrögð, petta sem verið er að kenna í skólanum, ef maður ... skilurðu, ef maður er að vinna á tímakaupi. pá vilja peir ađ mađur sé snöggur að vinna bara.

Pađ er pví ljóst ađ áhersla og markmið á námsstöđunum tveimur, skóla og vinnustađ, eru mjög ólík. Í skólanum er lögð höfuđáhersla á vandvirkni og gæđi en á vinnustađnum skilvirkni og afköst. 
Í viðtölunum kom pađ skýrt í ljós ađ öllum viðmælendum fannst vinnustađanámið mikilvægur hluti námsins. Til dæmis sagđi Gylfi, einn kennarinn:

Pað sjá allir gildi vinnustađanámsins, pað er mikið, par lærist tiltekin menning, par á að lærast virđing fyrir náminu sjálfu og iđninni í heild sinni, međferđá efni og öđru slíku. Færnipjálfunin liggur í vinnustađanáminu.

Einnig kom greinilega fram sú skođun kennaranna ađ ekki væri hægt ađ kenna allt í skóla og pví væri vinnustađanám nauđsynlegur hluti af náminu. Sveinarnir lögðu einnig allir mikla áherslu á mikilvægi vinnustađanámsins. Hannes komst svo að orđi: „En um leið og maður byrjar að vinna pá lærir maður miklu hrađar og miklu meira, hluti sem gagnast manni meira, skilurđu.“ Og pór sagđi: „Sumt fannst mér rosa barnalegt í pessum verklegu greinum [í skólanum], svo fannst mér verknámið miklu meira hardcore." Pađ er áhugavert í pessu samhengi ađ viđmælendur lögđu ekki sömu áherslu á mikilvægi skólahlutans. Má leiđa líkum ađ pví að sá hluti námsins pyki sjálfgefinn og hann purfi pví ekki að ræđa.

Sveinarnir ræddu pó um að skólinn væri oft í of mikilli fjarlægð frá vettvangi og pað væri mikilvægt að gæta pess að tengja námið við reynslu af vinnustað. Til dæmis sagði Hannes:

Um leið og maður kemur út á vinnumarkaðinn, pá fyrst fer maður að læra af viti. Maður lærir náttúrlega helling í skólanum, mađur lærir allan pennan grunn. En um leið og maður fer að starfa, pá, pađ breytir miklu, sko ... Ég er margoft búinn að hugsa um pađ, sko, ef ég hefđi verið búinn að gera eitthvað af pessu pegar ég hefði verið í skólanum, hvað pað hefði verið miklu betra.

Námið sem heild, samsett úr námi í skóla og á vinnustađ, var pannig nemendum hugleikið. Vitnað var til Hannesar hér ađ framan um mikilvægi pess að fá reynslu af vinnunni til ađ setja námið í skólanum í samhengi. Viktor var sama sinnis og lagđi áherslu á pađ hvernig bóklegar faggreinar hefðu, eftir á ađ hyggja, verið mikilvægari en hann gerđi sér grein fyrir:

pegar ég var sextán ára pá hafði ég ekki áhuga á [bóklegu fagi], pađ er eitthvađ sem ég hefði viljađ læra seinna, pegar ég væri búinn ađ átta mig ađeins meira á bví hvađ ég væri í rauninni að koma mér út í, sko.

Pessi dæmi sýna vel pau vandkvæði sem geta fylgt tvískipta kerfinu; sveinarnir höfðu stundum átt erfitt međ að tengja á milli pess sem var gert í skólanum og á vinnustađnum.

Í umræðu viðmælenda um pađ hvað einkenndi nám í skóla annars vegar og á vinnustað hins vegar komu fram skýr pemu tengd áskorunum hvors vettvangs fyrir sig. Pannig virtist pað vera mikilvægt fyrir skólann að geta gefið nemendum góða innsýn í vinnu við fagið og að halda í við próun fagsins. Petta átti einkum við í iðngreinum par sem vinnustađanámið var styttra og fór fram í síđari hluta námsins. Kennarar virtust átta sig mjög vel á mikilvægi pess að nemendur fengju innsýn í vinnuna við fagið á vettvangi og peim varð tíðrætt um hvernig hægt væri ađ leysa petta mál. Kynningar og heimsóknir á vinnustađi gegna par mikilvægu hlutverki, eins og Loftur, einn kennarinn, lýsti: „pú getur ekki kennt allt í skóla, pað er bara pannig. Pess vegna hef ég valið ... að fara með strákana rosalega mikið út á örkina og fara í skođunarferđir." Einnig sögđu kennarar frá styttri ólaunuđum vinnustađanámslotum (í eina til prjár vikur) sem eru hluti af áföngum í skóla. 
Viðmælendur ræddu töluvert um pær áskoranir skólans að halda í við próun fagsins á vettvangi. Loftur, einn kennarinn, komst svo að orđi pegar hann ræddi mikilvægi pess aঠ skólinn hefđi frumkvæði að pví að tengjast atvinnulífinu:

Við erum að búa til fólk, búa pađ undir ađ vinna í pessum greinum ... pú verđur ađ búa til fólk sem hentar í atvinnulífið. Ekki að vera međ gamlan hugsunarhátt og vera að leggja áherslu á eitthvað sem er dottið út ... pú verður að vera á tánum og fylgjast með hvað er í gangi til að skólinn staðni ekki.

Elín, meistari, lýsti svipađri skoðun, en lagđi áherslu á að pað væri erfiðara fyrir kennara að tileinka sér nýjungar en pá sem starfa í atvinnulífinu:

Margir kennarar verða samdauna sínu fagi, ef pú ert búinn að vera að kenna mjög lengi lokađur inni á stofnun og ert ekkert ađ kynna pér hvað er í gangi ... En yfirleitt purfa fyrirtæki, til pess að lifa verða pau að vera samkeppnishæf og í takt við tíđarandann.

Kennarar verđa pess vegna að hafa fyrir pví að setja sig inn í nýjungar í faginu og kennararnir sem rætt var við voru vel međvitađir um petta. Peir fóru pó ólíkar leiđir til pess og Markús, einn sveinninn, spurđi beint hvort kennurum væri gefið nægilegt rými í starfinu til ađ kynna sér nýja hluti.

Ein helsta áskorun vinnustađanámsins virđist vera sú ađ tryggja gæđi pess. Petta var sérstaklega áhyggjuefni kennaranna, eins og kemur fram í máli Gylfa:

Helsti bölvaldur vinnustađanámsins er hvað pað er misjafnt. pað er allt frá bví að vera mjög gott ... [og svo peir sem] eru ekki að rækja skyldur sínar. peir eru í rauninni bara međ ódýran vinnukraft. Nemendur hafa komið að máli við mig og sagt: „Ég lærði ekkert parna, eina sem ég lærđi var [nefnir afmarkað verkefni]." En pað er sú verkfærakista, sem er ekki full af verkfærum heldur hugmyndum og pekkingu og færni, sem pú vilt að nemandinn gangi út með. Sem hefur yfirfærslugildi. pessi menntun sem pau fá, ef menntun skyldi kalla, er svona verksmiðjumenntun. pau læra eitthvað afmarkað sem hefur ekkert yfirfærslugildi upp á ađrar aðstæður og par liggur hundurinn grafinn.

Samkvæmt kennurunum er hluta skýringarinnar ađ leita í pví hversu illa skilgreint vinnustađanámið er. Til dæmis sagđi Ásta:

En á međan petta er svona eins og petta er, að pađ er ekkert á bak við pessar einingar, pá er náttúrlega meistarinn frjáls. Eins og mér væri bara algerlega frjálst að gera ... pyrfti ekki að hafa neina kennsluáætlun og pyrfti ekki að hafa neitt. pau byrftu bara að mæta til mín og ég mundi bara láta pau prífa hérna í heila viku ... Ha? petta er svolítið sérstök uppbygging á námi.

Meistarar ræddu einnig gæði vinnustađanámsins, en pá tengdist pađ frekar umræðu um orđstír fagsins og vinnustađarins, eins og kemur fram hjá Tómasi: „Enda er pađ líka pannig að pví betri nemendur sem pú útskrifar, pví meiri heiður fær maður. pað er ekki gott að útskrifa lélegan fagmann."

Sveinarnir ræddu einnig um hve misjafnt vinnustaðanámið gæti verið. Flestir sveinanna lýstu góđri reynslu af vinnustađanámi sínu, eins og til dæmis Lára: „Peir pössuðu bað [að ég væri tilbúin] rosalega vel. Allavega par sem ég var. pað fer náttúrulega eftir vinnustaðnum en mér fannst ég alltaf vera tilbúin í pađ sem ég var send í.“ En sveinarnir höfðu allir sögur af slæmri reynslu annarra. Lára sagđi til dæmis: „,pað er bara á sumum 
stöðum, pá er bara verið að láta mann skúra og vaska upp á međan á öđrum stöđum pá ertu bara einn af starfsliđinu og færð pína ábyrgð.“ pór hafđi einnig góđa reynslu sjálfur en lýsti ástandinu almennt svona: „Petta er náttúrlega svo lítið land, pað er dálítið erfitt að setja alla í sama box, en hérna, petta er svo misjafnt hjá öllum nemendunum, sumir hafa petta ógeđslega líbó og sums stađar er petta bara ótrúlega mikið prælahald.“ Karen hafði svipađa sögu að segja, en lýsir hér reynslu bekkjarfélaga: „Hann var bara: Bíddu, ég sá að pú varst farin að [vinna], pú settir mynd á facebook? Já ... bíddu, ég er búin að vera í sex mánuđi að sópa gólf, sko." Pessir prír sveinar voru allir úr ólíkum iđngreinum, sjálfir með góđa reynslu af sínu vinnustađanámi en sögđu sögur af slæmri reynslu og misjöfnu vinnustađanámi annarra. Рað má spyrja sig hversu sannferđugar pær sögur eru og hvort pær gefi rétta mynd af stöđunni. Viktor, einn sveinninn sem rætt var við, hafđi sjálfur lent í slæmu vinnustađanámi sem varð til pess að hann hætti námi: „Ég var látinn vinna alveg rosalega mikið, ég var bara ódýr starfskraftur, ég var ekki að læra pað sem ég vildi vera að læra." pað var ekki fyrr en hann var farinn að vinna í faginu annars stađar, án réttinda, að meistarinn á peim vinnustað hvatti hann til að ljúka náminu:

Og ég slæ til. pá sá ég líka að pað var farið allt öđruvísi að hlutunum par ... En ég ræddi petta við meistarann pegar ég byrjađi, ađ ég vildi, pú veist, mig langar ađ ná langt í pessu, skilurđu

... getum við gert einhverjar æfingar hérna? pađ var ekkert mál. pað var bara, OK.

Viktor hafði pví mjög ólíka reynslu af pessum tveimur vinnustöðum. Miðað við að aðeins voru tekin viđtöl við átta sveina er áhugavert hversu ólíka reynslu peir höfđu innbyrđis, og rennir pað að einhverju leyti stođum undir pær fullyrđingar að vinnustaðanám sé á heildina litið æði misjafnt.

Tengt umræðu um gæði var pema sem sneri að námstækifærum í vinnustaðanáminu. Í máli viđmælenda kom fram ađ lítið væri um beina kennslu, heldur grundvallađist pjálfunin meira á frumkvæði nemenda að pví að bera sig eftir námstækifærum, eins og Sonja lýsti: „Maður lærđi af pví að gera. pað var ekkert alveg kennsla, maður bara spurđi.“ Vignir, einn meistarinn, lýsti pví einnig hvernig frumkvæđi nemenda skipti sköpum: „Petta er ofbođslega mikið í peirra höndum. Petta brýnum við fyrir peim. Pví meira sem pú vilt leggja á pig, pví meira leggjum við okkur fram. En ef pú sýnir engan áhuga pá er okkur slétt sama hvađ pú ert ađ gera." Í umræđu um petta benti Viktor á að pađ væri einnig á ábyrgð meistara að útvega námstækifæri: „Spurningin er líka, kunna nemarnir að spyrja um hvort pađ sé hægt að gera petta fyrir pá, sko [bera sig eftir námstækifærum]. En ættu peir að purfa að spyrja um pað, pað er líka spurningin, sko.“ Viðar, einn meistarinn, lýsti svipaðri afstöðu pegar hann sagði frá pví hvernig hann hefđi tekið að sér verkefni sem hann annars hefđi ekki gert, bara til ađ veita nemum tiltekna pjálfun, og einnig útbúið sérstaka æfingaaðstöđu á vinnustaðnum: „Svo reynum við að fylla upp með pví að hafa bara á vinnustađnum, eins og ég sagði, möguleika á æfingaađstöđu til peirra verka sem menn falla mest í [á sveinsprófinu]." Pannig virđist bæđi nemendum og meisturum vera annt um að skapa námstækifæri í vinnunni, en nokkuð líklegt er að ef annar hvor eđa báđir sinna pví ekki geti vinnustađanámið orđið rýrt.

Niðurstöđur sýna að markmið náms í skóla og á vinnustað eru ólík, en pessi markmið eru hvor tveggja mjög mikilvæg í starfsmenntun. Áskoranir hvors vettvangs fyrir sig endurspegluđu pessi ólíku einkenni námsins. 


\section{UMRÆEA}

Á heildina litið benda niðurstöđur til pess að tvískipta kerfið í löggiltum iðngreinum, eins og pað birtist í máli viðmælenda, sé rekið eins og tvö samhliða námskerfi frekar en ein samfelld heild. Samspil náms í skóla og á vinnustađ virtist vera óreiðukennt á köflum og ekki vel ljóst hvar ábyrgð lá á náminu í heild. Nemendur purfa sjálfir ađ útvega sér pláss í vinnustađanámi og skipuleggja samspil náms í skóla og á vinnustađ. Án efa skapar pađ góđan sveigjanleika fyrir nemendur til ađ haga náminu eftir pörfum en á móti kemur að nemandinn getur lent milli stafs og hurðar ef erfitt er að komast að í annaðhvort vinnustađanámi eđa skóla. Petta getur leitt til tafa í námi og í versta falli brotthvarfs. Nemendur í tveimur af peim fjórum iðngreinum sem voru í úrtakinu höfðu lent í erfiðleikum við að komast á samning, og petta er vafalítið háđ ástandi og stöđu einstaka greina. Eđlilegt er pó að spyrja hvort pað eigi ekki að vera á ábyrgð menntakerfisins að tryggja að nemendur geti lokið námi ef peir hafa sinnt pví eins og til er ætlast. Eins og stađan er núna gerir kerfið pađ ekki. Velta má fyrir sér hvort petta fyrirkomulag eigi einhvern pátt í miklu brotthvarfi nemenda úr starfsmenntun á Íslandi (OECD, 2013) og geti mögulega fælt pá frá pví að velja sér starfsmenntun.

Tengsl á milli skóla og vinnustađar voru almennt óformleg og byggđust á persónulegum samböndum kennara og meistara. Einhverjar upplýsingar virtust berast međ nemendum pegar peir fóru á milli stađa. Pannig virđist uppbygging tvískipta kerfisins í löggiltum iðngreinum, samkvæmt niðurstöðunum hér, almennt falla að hinni hefðbundnu nálgun hvað varđar samspil náms í skóla og á vinnustađ. Par er gert ráđ fyrir ađ nám gerist sjálfkrafa við pađ ađ nemandi vinni á vettvangi og samskipti og samhæfing skóla og vinnustađar séu óparfi (Guile og Griffiths, 2001; Tynjälä, 2008). Rannsóknir hafa pó sýnt hið gagnstæđa, og að samræming og samfella í tvískipta kerfinu sé mikilvæg (Billett, 2014; Mulder o.fl., 2015; Schaap o.fl., 2012; Sloane, 2014; Tynjälä, 2008). Líklegt er að par sem kennarar og meistarar eru í góðum samskiptum, og niðurstöðurnar sýna dæmi um slíkt, sé annað upp á teningnum, en gallinn er að kerfið í heild er ekki sett upp til að tryggja pessa samvinnu. Leiđa má að pví líkum að petta sé ein af ástæðum pess að vinnustađanám sé eins misjafnt og niðurstöđurnar gefa til kynna.

Niðurstöđurnar sýna pó tvímælalaust að bæđi kennarar og meistarar eru gagnrýnir á pessa tilhögun kerfisins, og allir vilja meiri og formlegri samskipti, sérstaklega til að tryggja gæði námsins. Vandamálið virđist međal annars liggja í pví að pessi samskipti hafa ekki verið formgerð í kerfinu í raun sem hluti af skyldum og vinnu kennara og meistara. Viðmælendur virtust átta sig á pessu en ekki vera sammála um hvađa leið bæri að fara eđa hver ætti að bera parna ábyrgð. Hugsanlega er petta birtingarmynd vissrar togstreitu í eignarhaldi starfsmenntunar á milli skólakerfis og meistarakerfis. Eins og nám í löggiltum ¡đngreinum á Íslandi er útfært í dag virđist afstađa í pessum málum einnig vera ólík eftir iđngreinum og pví hvort meginhluti peirra er kenndur í skóla eđa á vinnustað (sjá einnig Elsu Eiríksdóttur, í prentun).

Viðmælendur voru sammála um mikilvægi vinnustađanámsins, en greinilegt er að hér, líkt og annars stađar, hafa menn áhyggjur af pví hvort nemendur fá pá pjálfun sem til er ætlast (sjá t.d. Billett, 2009; Eraut, 2004; Tynjälä, 2008). Umræđa um námstækifæri hvernig best sé að veita pau og nýta - gefur til kynna að viðmælendur telji margir hverjir 
mikilvægt að huga að kennslufræðilegri uppbyggingu vinnustaðanámsins. Ein leið til að tryggja gæði vinnustađanáms er til dæmis að nota ferilbækur, par sem haldið er utan um verkefni nemenda. Varđandi ferilbækur eða önnur verkfæri sem eiga að tryggja gæði vinnustađanáms verđur að hafa í huga hvernig pau geta nýst til að efla samskipti og samvinnu kennara og meistara svo pau verđi ekki bara formlegri útfærsla á upplýsingaflæđi frá nemendum.

Niðurstöđur um einkenni námsins í skóla og á vinnustađ samræmast fyrri rannsóknum á tvískipta kerfinu sem sýna að námið á pessum stöđum er ólíkt en bætir hvort annað upp (sjá t.d. Aarkrog, 2005; Billett, 2009; Fuller og Unwin, 2004a, Griffiths og Guile, 2003; Lindberg, 2003; Schaap o.fl., 2012). Niðurstöđurnar hér sýna glöggt hverjar áskoranir hvors námsstađar eru og hvernig styrkleikar námsins í skólanum (skýrt skilgreind markmið, verkefni sem byggja markvisst upp hæfni og áhersla á gæđi og vandvirkni) eru veikleikar námsins á vinnustađ. Og öfugt, pví styrkleikar námsins á vinnustađ (áhersla á skilvirkni og hrađa, raunhæf verkefni á vettvangi og að halda í við próun fagsins) eru veikleikar náms í skóla. pví mætti ætla að nemendur fengju góđa heildstæđa pjálfun sem fagmenn í tvískipta kerfinu á Íslandi. Í flestum tilvikum er pađ sennilega svo - en pó er ljóst af niðurstöđunum að víđa mætti lagfæra fyrirkomulag til að tryggja heildstætt samspil náms í skóla og á vinnustađ og samstarf međ nemandann í forgrunni. Til að vinna að pví markmiđi er brýnt að skilgreina vandlega ábyrgð og utanumhald á námi nemandans frá upphafi til enda náms hans. Ekki er síđur mikilvægt ađ gera samvinnu og samskipti um nám nemenda að skilgreindu verkefni í kerfinu. Petta parf bæði að vera á grundvelli einstaklinga (kennara og meistara) og hópa (skóla og fyrirtækja). Pannig væru til dæmis skilgreindir sem verkefni reglubundnir fundir kennara og meistara með nemanda par sem farið væri yfir stöđu nemandans í náminu í heild. Einnig parf kerfisbundna samvinnu skóla og vinnustađar til að vinna upp á móti veikleikum hvors námsstađar: Tryggja parf að nemendur fái innsýn í vinnu við fagið í skólanum, ekki síst snemma á námsferlinum, og að námið par haldi í við próun fagsins. Svo parf að tryggja gæđi námsins og að nemendur fái pau námstækifæri sem til parf á vinnustađnum. Petta krefst víđtæks samstarfs skóla og vinnustađa, til dæmis með kynningum á starfsemi og nýjungum í fyrirtækjum, verkefnum unnum bæði í skóla og á vinnustað, og með pví að opna umræðu um hvað skuli kenna hvar og hvernig. Víđa eru verkefni af pessu tagi í gangi, en oft eru pau á vegum einstakra kennara eđa tímabundin. Í stađinn ættu pau að vera veigamikill páttur í reglulegu og formgerđu samstarfi skóla og vinnustađar í tvískiptu kerfi starfsmenntunar.

\section{ATHUGASEMD}

1 Pegar rannsóknin var gerđ voru eingöngu til stađfestar námskrár fyrir 34 löggiltar iðngreinar. 


\section{HEIMILDIR}

Aarkrog, V. (2005). Learning in the workplace and the significance of schoolbased education: A study of learning in a Danish vocational education and training programme. International Journal of Lifelong Education, 24(2), 137-147. https://doi.org/10.1080/02601370500056268

Billett, S. (2009). Vocational learning: Contributions of workplaces and educational institutions. Í R. Maclean og D. Wilson (ritstjórar), International handbook of education for the changing world of work (bls. 1711-1723). Dordrecht: Springer.

Billett, S. (2013). Recasting transfer as a socio-personal process of adaptable learning. Educational Research Review, 8, 5-13. https://doi.org/10.1016/j.edurev.2012.05.004

Billett, S. (2014). Integrating learning experiences across tertiary education and practice settings: A socio-personal account. Educational Research Review, 12, 1-13. https:// doi.org/10.1016/j.edurev.2014.01.002

Bjurulf, V. (2013). Transfer as an iterative process between school and work: The LISAprjoect. Í H. E. Middleton og L. K. J. Baartman (ritstjórar), Transfer, transitions and transformations of learning (bls. 39-48). Rotterdam: Sense Publishers.

Braun, V. og Clarke, V. (2006). Using thematic analysis in psychology. Qualitative Research in Psychology, 3(2), 77-101. https://doi.org/10.1191/1478088706qp063oa

Brooker, R. og Butler, J. (1997). The learning context within the workplace: As perceived by apprentices and their workplace trainers. Journal of Vocational Education and Training, 49(4), 487-510. https://doi.org/10.1080/13636829700200028

Bryman, A. (2012). Social research methods (4. útgáfa). Oxford: Oxford University Press.

Cedefop. (2011). Glossary: Quality in education and training. Luxembourg: Publications Office of the European Union.

Cedefop. (2015). Spotlight on VET - Anniversary edition: Vocational education and training systems in Europe. Luxembourg: Publications Office of the European Union.

Cornford, I. og Gunn, D. (1998). Work-based learning of commercial cookery apprentices in the New South Wales hospitality industry. Journal of Vocational Education and Training: The Vocational Aspect of Education, 50(4), 549-568. https://doi. org/10.1080/13636829800200062

Elsa Eiríksdóttir. (2012). Raunvísinda- og tæknimenntun: Stađa íslenskra nemenda og framtíđarpörf samfélagsins: Skýrsla starfshóps á vegum Mennta- og menningarmálaráđuneytis, Samband íslenskra sveitarfélaga og Samtaka iđnađarins. Reykjavík: Samtök iðnađarins, Mennta- og menningarmálaráđuneyti og Samband íslenskra sveitarfélaga. Sótt af http://www.si.is/media/menntamal-og-fraedsla/GERT-Skyrsla-2012-nytt.pdf

Elsa Eiríksdóttir. (í prentun). Variations in implementing the dual VET system: Perspectives of students, teachers and trainers in the certified trades in Iceland. Í S. Choy, G.-B. Wärvik, V. Lindberg og I. Berglund (ritstjórar), Integration of vocational education and training experiences: Purposes, practices and principles. Dordrecht, Springer.

Eraut, M. (2004). Informal learning in the workplace. Studies in Continuing Education, 26(2), 247-273. https://doi.org/10.1080/158037042000225245

Flick, U. (2014). An introduction to qualitative research (5. útgáfa). London: Sage. 
Forsætisráđuneytið. (2012). Allir stundi nám og vinnu við sitt hæfi: Tillögur um sampættingu menntunar og atvinnu. Sótt af http://hdl.handle.net/10802/6151

Fuller, A. og Unwin, L. (2004a). Expansive learning environments: Integrating organizational and personal development. Í H. Rainbird, A. Fuller og A. Munro (ritstjórar), Workplace learning in context (bls. 126-144). London: Routledge.

Fuller, A. og Unwin, L. (2004b). Young people as teachers and learners in the workplace: Challenging the novice-expert dichotomy. International Journal of Training and Development, 8(1), 32-42. https://doi.org/10.1111/j.1360-3736.2004.00194.x

Griffiths, T. og Guile, D. (2003). A connective model of learning: The implications for work process knowledge. European Educational Research Journal, 2(1), 56-73. https://doi. org/10.2304/eerj.2003.2.1.10

Guile, D. og Griffiths, T. (2001). Learning through work experience. Journal of Education and Work, 14(1), 113-131. https://doi.org/10.1080/13639080124403

Guile, D. og Young, M. (2003). Transfer and transition in vocational education: Some theoretical considerations. Í T. Tuomi-Gröhn og Y. Engström (ritstjórar), Between School and work: New perspectives on transfer and boundary-crossing (bls. 63-81). Oxford: Elsevier Science.

Hagstofa Íslands. (2017). Kynjahlutfall nemenda í iðngreinum. Sótt af http://px.hagstofa. is/pxis/pxweb/is/Samfelag/Samfelag_skolamal__3_framhaldsskolastig__o_ fsNemendur/SKO03101.px/

INAP Commission 'Architecture Apprenticeship'. (2013). Memorandum: An architecture for modern apprenticeships: Standards for structure, organisation and governance. Í L. Deitmer, U. Hauschildt, F. Rauner og H. Zelloth (ritstjórar), The architecture of innovative apprenticeship (bls. 1-24). Dordrecht: Springer.

Jón Torfi Jónasson. (1998). The foes of Icelandic vocational education at the upper secondary level. Í A. Tjeldvoll (ritstjóri), Education and the Scandinavian welfare state in the year 2000: Equality, policy, and reform (bls. 267-303). New York: Garland.

Kvale, S. (1996). Interviews: An introduction to qualitative research interviewing. Thousand Oaks: Sage.

Lindberg, V. (2003). Vocational knowing and the content in vocational education. International Journal of Training Research, 1(2), 40-61. https://doi.org/10.5172/ijtr.1.2.40

Mennta- og menningarmálaráđuneytið. (2010). Mótun stefnu um nám alla ævi: próun menntastefnu á Íslandi i evrópsku samhengi. Reykjavík: Höfundur.

Mennta- og menningarmálaráđuneytið. (2014). Hvítbók um umbætur í menntun. Reykjavík: Höfundur.

Mulder, R. H., Messmann, G. og König, C. (2015). Vocational education and training: Researching the relationship between school and work. European Journal of Education, 50(4), 497-512. https://doi.org/10.1111/ejed.12147

Naidu, R. (2013). Glossary of VET. J. Stanwick og K. Frazer (ritstjórar). Adelaide: National Centre for Vocational Education Research.

Nielsen, K. og Kvale, S. (2006). The workplace - a landscape of learning. Í E. Antonacopoulou, P. Jarvis, V. Andersen, B. Elkjaer og S. Høyrup (ritstjórar), Learning, working and living: Mapping the terrain of working life learning (bls. 119-135). Basingstoke: Palgrave Macmillan. 
OECD. (2009). Learning for jobs: OECD policy review of vocational education and training: Initial report. París: Höfundur.

OECD. (2013). Yfirlitsskýrsla OECD um starfsmenntun á Íslandi: Leikni að loknum skóla. Reykjavík: Mennta- og menningarmálaráđuneytið.

Reglugerđ um löggiltar iðngreinar nr. 940/1999.

Reglugerđ um vinnustađanám og starfspjálfun á vinnustað nr. 840/2011.

Ríkisendurskođun. (2017). Starfsmenntun á framhaldsskólastigi: Skipulag og stjórnsýsla. Reykjavík: Höfundur. Sótt af https://rikisendurskodun.is/wp-content/ uploads/2017/04/SU-Starfsmenntun-a-framhaldsskolastigi.pdf

Schaap, H., Baartman, L. og de Bruijn, E. (2012). Students' learning processes during school-based learning and workplace learning in vocational education: A review. Vocations and Learning, 5(2), 99-117. https://doi.org/10.1007/s12186-011-9069-2

Sloane, P. F. E. (2014). Professional education between school and practice settings: The German dual system as an example. Í S. Billett, C. Harteis og H, Gruber (ritstjórar), International handbook of research in professional and practice-based learning (bls. 397-425). Dordrecth: Springer.

Stýrihópur 20/20 sóknaráætlunar. (2010). Niđurstöđur 20/20 sóknaráætlunar. Reykjavík: Höfundur. Sótt af https://www.stjornarradid.is/media/forsaetisraduneyti-media/ media/2020/Soknaraaetlun2020Lokaskyrsla.pdf

Tynjälä, P. (2008). Perspectives into learning at the workplace. Educational Research Review, 3(2), 130-154. https://doi.org/10.1016/j.edurev.2007.12.001

Wahlgren, B. (2009). Transfer mellem uddannelse og arbejde. Kaupmannahöfn: Nationalt Center for Kompetenceudvikling.

Greinin barst tímaritinu 7. september 2017 og var sampykkt til birtingar 25. október 2017

\section{UM HÖFUNDINN}

Elsa Eiríksdóttir (elsae@hi.is) er lektor í kennslufræđi verk- og starfsmenntunar við Menntavísindasvið Háskóla Íslands. Hún lauk BA-prófi í sálfræđi frá Háskóla Íslands 1999 og meistara- og doktorsprófi í verkfræđilegri sálfræđi frá Georgia Institute of Technology í Atlanta í Bandaríkjunum 2007 og 2011. Rannsóknaráhugi hennar beinist ađ námi og yfirfærslu, próun kunnáttu og verk- og starfsmenntun. 


\title{
Learning in school and at the workplace: Perspec- tives of recent graduates, teachers, and workplace trainers in the dual system of certified trades in Iceland
}

\begin{abstract}
In Iceland the vocational education and training (VET) system is generally organized as a dual system, where some of the training takes place at school and some at the workplace. Research has shown that learning at these different sites provides a complementary experience, in terms of, for example, different opportunities for learning and development of competencies (see Aarkrog, 2005; Billett 2009; Bjurulf, 2013; Eraut, 2004; Fuller \& Unwin, 2004b; Griffiths \& Guile, 2003; INAP Commission 'Architecture Apprenticeship', 2013; Lindberg, 2003; Schaap, Baartman, \& de Bruijn, 2012). Research has, however, also shown that the effectiveness of the dual system is in part based on the coherence of the learning that takes place at each site. Transfer of learning from the school to the workplace and vice versa is often elusive, and students have difficulty making sense of how what they learn at school is relevant to work and how experiences at the workplace relate to what is discussed at school (Billett, 2013, 2014; Guile \& Young, 2004; Mulder, et al., 2015; Schaap, et al., 2012; Sloane, 2014; Tynjälä, 2008; Wahlgren, 2009). The goal of the research was to investigate how the dual system in the certified trades (where a journeyman's examination is required for working in the trade) is implemented in Iceland and, specifically, to look at whether the system provides a coherent educational experience in terms of how educational pathways are organized. This involves the characteristics of learning experiences at school and at the workplace, and connections and relationships among relevant parties at each site.
\end{abstract}

Recent graduates, teachers, and workplace trainers in four trades, selected as representatives of different dual system variations in the Icelandic VET system, were interviewed (8 participants in each group; $N=24$ ). The semi-structured interviews focused on how the school- and work-based learning parts were integrated in practice, and the perceived benefits and faults of the current implementation. The interviews were recorded and transcribed for analysis. The analysis was both based on the interviews' topical structure as well as thematic analysis (Braun \& Clarke, 2006).

The results showed that the dual system in certified trades in Iceland is organized in the form of parallel courses rather than being integrated in a single educational track. It seems unclear who is responsible for the students and the program as a whole. The students themselves are responsible for securing a work-based contract and organizing the integration of work-based and school-based periods. This can provide flexibility for students but can also result in delays, or in worst cases, dropout, if contracts are hard to come by or if it is difficult to complete the school-based part of the program. Relations between teachers and workplace trainers were informal and dependent on whether the individuals knew each other personally. As a result, it varied whether discussions on the 
students' progress took place and to what degree. In many cases the students themselves seemed to provide the information. However, it was clear that both the teachers and the workplace trainers were very much interested in having both more formal and frequent communication, mostly as a strategy to ensure the quality of education provided. The results on the characteristics of the learning experiences at school and work are in accordance with prior research, and show that these experiences are different but complementary. The strengths of the school-based part of the program (well defined objectives, tasks targeting specific skills, and emphasis on quality and accuracy) were also the challenges for the work-based part. And vice versa: The strength of the workbased part (emphasis on efficiency and speed, realistic on-site tasks, and keeping up with developments in the field) were all challenges for the school-based part. Overall, the results, therefore, indicate that through studying both at school and at the workplace, students in certified trades in Iceland have opportunities for comprehensive and relevant education in their chosen vocation - but also that more could be done to ensure that the program forms a coherent whole, ensuring transfer of knowledge and skills between school and work.

Keywords: vocational education and training, dual education system, apprenticeship, work-based learning, upper secondary education

\section{ABOUT THE AUTHOR}

Elsa Eiriksdottir (elsae@hi.is) is an assistant professor at the University of Iceland, School of Education. She completed a BA-degree in psychology from the University of Iceland in 1999 and a Master's and a PhD in engineering psychology from Georgia Institute of Technology in Atlanta in 2007 and 2011 respectively. Her research interests include learning, transfer of training, skill acquisition, and vocational education and learning. 